\title{
The bioethics of "malice" and the concept of imputability in the criminal trial, in the light of the Orlando reform and the contribution of neuroscience to the Forensic psychopathology
}

\author{
Celeste Oranges \\ Graduated in Law, II Level Master in Criminology and Security at UNINT, University of International Studies of Rome, \\ Italy
}

\begin{abstract}
Malice, crime and madness have in themselves an intrinsically fascinating nature, which has led scholars of all kinds to question on their relationship, on their genesis, but also on their same semantic meaning. For some time, the legal professions are discussing on the original or derived essence of the wickedness and its incidence of the same mental health of the "bad" individual, without leading to certain answers. After all, a rigid and univocal solution of complex problems can lead to erroneous and dangerous conclusions since the human behavior does not lend to simplistic explanations. Our inborn inclination in the need to achieve clarifying answers and that will undermine our need to distinguish the world in good and bad, right and wrong, healthy or crazy, bad or good, leads to the creation of watertight concepts, meaningless of real results. Paradoxically we more persist in the search for clear and define solutions the more we move away from the reality of the facts. This being the case does not involve the renunciation of investigating the mechanisms that regulate the human behavior, but sets the basis to make a realistic investigation. The human act is not determined by a single factor, whether biological, psychological or environmental, but from multiple reasons and also from an intangible component of randomness. So, also the action of the villain or the criminal cannot be explained through a blind causal determinism, but through the use of medicines, of the psychology, of the anthropology and all others sciences useful to provide additional factors to our research. However, the neuroscientific approaches are interesting, which have shown that there is a real correlation between special genes (which for example, the MAOA, Monoamine Oxidase A) or between the brain loops linked to the emphatic answer (such as the anterior cingulate cortex, the insula and the amygdala) and the attitude to crime, understood as greater violent acts by the subject examined. These objectives reached in the science must be remain unenforceable and can certainly provide a valuable contribution even to decide in the judicial matters, in order to equip the Court of more elements to decide of the guilt and of the imputability of the subject accused of a crime. Special attention must be given to the science that it is not allowed to be a guru that uncritically analyses the bases of the free will, while excluding the others probative results on which the Court must expressed his conviction, for the purpose of the judgement. In this context we place also the perennial dilemma of the vices of the human mind and the imputability. Indeed, the concept of "mental infirmity" gets a different meaning depending on whether we are considering the same medical or legal point of view. Unique is the interpretative evolution about the concept of the mental infirmity suffered by the legal point of view, rapidly widening gap compared with the clinic concept of the mental pathology and opening doors also to so called "personality disorders". An essential contribution to the problem arising from the Law of $23^{\text {rd }}$ June 2017, n. 103, as called Orlando Reform, which introduced some amendments to the Criminal Code, to the Criminal Procedure Code and to Penitentiary system. Among the points of the Reform, of peculiar interest it's the choice of the legislator to fill a gap in the system in terms of imputability and mental infirmity, addressing personality disorders and finally affixing the seal of legality to the doctrinal and jurisprudential theses on the subject. These theoretical principles have provided into action in the analysis of certain cases concerning blood offences, after having given a starting point on concept of free will, of mental infirmity, of determinism behavior, and on the relationship between science and Law, in a helpful interest.
\end{abstract}

\section{RIASSUNTO}

Cattiveria, crimine e follia hanno in sé una natura intrinsecamente affascinante, che ha portato studiosi di ogni genere ad indagare sul loro rapporto, sulla loro genesi, ma anche sul loro stesso significato semantico. Da tempo i giuristi si interrogano sulla essenza, originaria o derivata, della cattiveria e sulla incidenza della stessa nella salute mentale dell'individuo "cattivo", senza pervenire a risposte certe. Del resto, una soluzione rigida ed univoca di problemi complessi può condurre a conclusioni errate e pericolose in quanto il comportamento umano non si presta a spiegazioni semplicistiche. La nostra innata esigenza di ottenere delle risposte chiarificatrici e che plachino il nostro bisogno di distinguere il mondo in bene e male, giusto e sbagliato, sano o folle, cattivo o buono, porta alla creazione di concetti stagni, privi significato reale. Paradossalmente più ci si ostina nella ricerca di soluzioni chiare e nette più ci si allontana dalla realtà dei fatti. Questa premessa non comporta la rinuncia ad investigare sui meccanismi che regolano il comportamento umano, ma pone le basi per rendere un'indagine realistica. L'agire dell'uomo non è determinato da un solo fattore, che sia questo biologico, psicologico o ambientale, ma da multiple cause e anche da un'intangibile componente di casualità. Quindi, anche l'agire del cattivo o del criminale non può essere spiegato attraverso un cieco determinismo causale, bensì attraverso l'utilizzo della medicina, della psicologia, dell'antropologica e di tutte le altre scienze utili a fornire elementi utili alla nostra ricerca. Interessanti senza dubbio sono gli approdi neuroscientifici, che hanno dimostrato che esiste una reale correlazione tra particolari geni (quali, ad esempio, il MAOA, Monoamine Oxidase A) o tra i circuiti celebrali legali alla risposta empatica (come la corteccia cingolata anteriore, l'insula e l'amigdala) e l'attitudine al crimine, intesa come maggiore probabilità di compiere atti violenti da parte del soggetto esaminato. Questi traguardi della scienza non devono rimanere inattuati e possono senza dubbio fornire un prezioso apporto anche in ambito giudiziario, al fine di munire il giudice di più elementi per decidere della colpevolezza e dell'imputabilità del soggetto accusato di un reato. L'attenzione deve essere rivolta a non trasformare la scienza in un guru che spieghi acriticamente le basi del libero arbitrio, escludendo le altre 
risultanze probatorie sulle quali l'organo giudicante deve poter fondare il suo convincimento, ai fini dell'emanazione della sentenza. In tale contesto si inserisce anche l'annoso dilemma tra vizi di mente e imputabilità. Il concetto di "infermità mentale" acquista, infatti, un'accezione diversa a seconda che si prenda in considerazione la stessa da un punto di vista medico o giuridico. Singolare è l'evoluzione interpretativa che il concetto di infermità mentale ha subito da un punto di vista giuridico, ampliandosi sempre di più rispetto alla concezione clinica della patologia mentale ed aprendo le porte anche ai cosiddetti “disturbi di personalità". Un apporto rilevante al problema deriva dall'adozione della legge del 23 giugno 2017, n. 103, c.d. riforma Orlando, che ha apportato modifiche al codice penale, al codice di procedura penale ed all'ordinamento penitenziario. Tra i punti della riforma, di peculiare interesse risulta la scelta del legislatore di colmare una lacuna dell'ordinamento in tema di imputabilità ed infermità mentale, affrontando i disturbi di personalità ed apponendo finalmente il sigillo di legalità alle tesi dottrinarie e giurisprudenziali sulla materia. Questi principi teorici hanno trovato riscontro concreto nell'analisi di alcuni casi riguardanti reati di sangue, che hanno offerto lo spunto per riflettere sui concetti di libero arbitrio, di infermità mentale, di determinismo comportamentale, e sul rapporto tra scienza e diritto, in un'ottica collaborativa tra le due culture.

\section{RESUME}

Maldad, crimen y locura tienen en su intrínsecamente una natura fascinante, que han llevado investigadores de diferentes géneros a profundizar en su relación sobre su creación y sobre el mismo significado semántico. Hace tiempo los juristas sobre la esencia, original o derivada, de la maldad y de su importancia en la salud mental del individuo "malo" sin alcanzar respuestas definitivas. De hecho, algún tipo de respuesta rígida y unívoca de problemas de problemas complejos puede llevar a conclusiones equivocadas o peligrosas ya que la conducta humana no permite explicaciones simples. Nuestra innata exigencia de obtener respuestas clasificadoras y que apacigüen nuestras exigencias de diferenciar el mundo en bien y mal, correcto o equivocado, cuerdo o loco, malo o bueno, lleva a la creación de conceptos estancados, desprovisto de su real significado. Paradójicamente cuanto más intentamos buscar soluciones claras, más nos alejamos de la realidad de los hechos. Esta premisa no conlleva una renuncia a la investigación de los mecanismos que determinan la conducta humana, sino que quiere plantear las bases para una investigación más realista. El hacer del hombre no se determina por un solo factor, sea biológico, psicológico o ambiental, sino por múltiples causas y una intangible componente de casualidad. Por eso también el actuar del malo o del criminal, no se puede explicar a través de un único factor causal, más bien a través de la ayuda de la medicina, de la psicología, de la antropología y de todas las demás ciencias útiles a aportar elementos preciosos para nuestra investigación. Sin duda se están demostrando interesantes los últimos descubrimientos neurocientificos, que han conseguido demostrar una correlación de genes específicos (por ejemplo, MAOA, Monoaminas, Oxidase A) o de los circuitos cerebrales relacionados con la respuesta empática (como el Cortez cingulado anterior, la ínsula y la amígdala), y la actitud hacia la conducta criminal entendida como una mayor probabilidad de cumplir actos violentos por parte del subjetivo en examen. Estos logros de las ciencias no tienen que quedarse de lado y pueden aportar sin dudas una preciosa ayuda también a nivel judiciario con el fin de propinar el juez de mayores elementos para decidir la culpabilidad o la inimputabilidad del sujeto acusado del un delito. La atención no debería de estar dirigida a transformar las ciencias en un gurú de explique de forma acrítica las bases del libre albedrío, excluyendo las otras resultancias probatorias de las cuales el órgano juzgarte tiene que poder fundar sus convicciones para una sentencia. Es en este complicado contexto que se encuentra el dilema entre vicios de la mente y inimputabilidad, el concepto de enfermeras mental adquiere un significado diferente según estemos hablando de un contexto médico o de uno jurídico. Característica es la evolución interpretativa que el concepto de enfermedad mental desde el punto de vista jurídico, ampliándose cada vez más al concepto de enfermeras mental desde el punto de vista clínico, abriendo cada vez más las puertas a los definidos "trastornos de la personalidad". Una importante aportación al problema deriva a raíz de la aplicación de la ley del 23 de junio 2017, n. 103, definida reforma Orlando que presentaba modificaciones del código penal, al código de procedimiento penal y al ordenamiento penitenciario. Los puntos de más interés de la reforma resultan ser la eleccionaria del legislador para rellenar las lagunas del ordenamiento en las partes de inimputabilidad y enfermeras mental, tratando el tema de los trastornos de personalidad y aportando por fin legalidad a las tesis doctrinales y de tipo jurídico sobre el tema. Estos principales teóricos se han encontrado en concreto en el análisis de delitos de sangre, que han ofrecido la posibilidad de reflexionar sobre el tema de libre albedrío en la enfermadas mental, de determinismo conducir al, y de la relación entre ciencias y derecho, en una visión que prevé colaboración entre estas dos partes.

\section{Introduction}

The emphasis to the concept of good and evil dates back to the ancient world and the study of the human character has been totally object of interest by many branches of the human knowledge.

In the $2^{\text {nd }}$ century B.C., the Latin playwright Plauto wrote about "lupus est homo homini"1, a concept that reflects the ancient vision of the selfish nature of the human being.

In particular, following the philosopher Thomas Hobbes ${ }^{2}$, the natural condition of the human being is that to cancel anyone who is an obstacle to satisfy its needs and if there were the state of nature, which is a state not governed by laws, there was an endless war between them all, "bellum omnium contra omnes", that it has never happened only thanks to the social and political covenant concluded between the human race.

The suspicion is that the human being has an inborn aggressive nature and that the evil tendency is an intrinsic characteristic of the human being. In this context, Freud claimed that the human being "isn't a friendly creature" as in itself "aggressive instinct and primitive passions which lead to the ravishment, to the incest, to the murder; it has held back, in an imperfect way, by the Social Institutions and by guilt" but, "when the conflicting psychic forces that usually inhibit it stop working, which happens naturally and shows in the human being a wild beast, to which it is not in any way

R. Koselleck \& R. Schurr, Hobbes-Forschungen, Duncker \& Humblot, Berlino, 1969, pp. 61-70.

2 Thomas Hobbes (Westport 5 april 1588 - Hardwic Hall 4th december 1679) British philosopher and mathematician, supporter of natural Law and author in 1651 of the philosophical-political test Leviathan.

3 T. Hobbes, De Cive, Marietti Editori, Torino, 1972, p. 24. 
linked the respect for their own species"4. The thesis of the innate evil nature is shared also by Edgar Allan Poe who, in his novel The imp of the perverse ${ }^{5}$, is translatable as "il denome innato del perverso" or "della perversità", he explained the cryptic and dark inclination that drives the human race and that lead the human being to develop an aggression which goes far beyond the adaptive need and the beast survival, running out to destroy the others and itself.

The subject of the malice is more than ever timely today, in the light of the insane terrorist massacres ${ }^{6}$ of Jihadist origin, which for too many years have been spreading the blood of innocent victims to the cry of "Allāhu Akbar".

It is hard to find a sense for the about 3000 victims on $11^{\text {th }}$ September 2001 in New York, where they were submerged by the rubble of the Twin Towers World Trade Center; for the massacre of Nice, where under a truck of 19 tons have been crushed forever the lives of 84 human beings; for the massacres of Brussels, Paris, London, Madrid, but also Istanbul, Bali, Ankara, Nairobi and many others cites, affected by attacks claimed by Isis.

Faced with these events of an inexplicable brutality and emotionally unreasonable, it would automatically be thought that we are facing people mentally disturbed, but we would fall into an approximate, dangerous and above all wrong deduction. Indeed, in the scientific literature, many agree that the terrorists are not necessarily "matti"7. There are many scholars who pronounced on the subject, embracing the thesis of genetic predisposition to violence and malice, so much as to come to assert that the attitude to evil would even be measurable.

The progenitor of clinical criminology is Cesare Lombroso, who introduced the concept of "Natura Criminale", asserting that, from anatomical and congenital characteristics, it is possible to identify the individual prone to crime, regardless of the environmental conditions (Teoria del delinquente nato) ${ }^{8}$. According to the Lombrosian Theory of biological determinism, the crime is seen as a disease that must be treated and not as the result of a free choice of the offender. These theories, which seemed to have been overcome, they are now come back in the spotlight thanks to the evolution of neuroscience and their application in the penal process.

In particular, recently the psychiatrist and criminologist Adrian Raine, in his essay titled provocatively "The anatomy of violence", has taken the Lombrosian Theories of the predisposition to crime on the basis of defects in the brain structure, integrating them, however, with the studies on social determinism. Raine has associated the antisocial behaviors with certain conformations of the brain (in particular, the prefrontal cortex, the posterior cingulate cortex, the amygdala and the hippocampus), declaring that these irregularities in the cerebral structure are determined by social and genetic factors.

Simon Baron-Cohen also has tried to find the explanation of evil and he did it trying to move the debate on the causes of evil from the religious to the scientific area. For the Author, to understand the human cruelty, we need to replace the generic term "evil" with the scientific word "empathy"10.

Baron-Cohen defined empathy as "our ability to identify what someone is thinking or feeling, and to answer to those thoughts and feelings with a corresponding" or, anyway, "appropriate"11 emotion, claiming that by analyzing the circuit of empathy, also through the magnetic resonance, it is possible to verify the subjects with a low empathy, that they will be those more inclined to act in a cruel way.

Always with regard to the fascination that the etiology of criminal conduct exerts on the human being, it is necessary to highlight how many others studies have focused on the influence that the environment can have on human behavior and, in particular, on the violent action. In the late 1990s, interviews were conducted with 250 Palestinian Hamas and Jihadist members from whom emerged (from the clarity of the histories about the terrorist attacks and the resulting victims) the absence of major psychopathologies in the individuals interviewed. From some studies it has been found that, in the practice of enlistment, the Islamic State prefers the selection of "reliable" people, not affected by important mental imbalances. Among the 11 recruitment requirements required to the agent of Allah there are: being cunning, intelligent, calm, able to resist to the arrest and to the prison, face the trauma of murder and massacres $^{12}$.

Even more incorrect it would be to give these actions a simplistic religious, ideological or cultural label; in fact, often behind the massacres or the gestures of the so-called "lone wolves", hides that pathology known as "Samson's syndrome"13 and that in the United States it is called "Berserker's syndrome"14, which are frustrated individuals who act in order to affirm their own will of vengeance towards the society or, in any case, those who consider

4 S. Freud, Il disagio della civiltà, 1929, in Opere, Vol. 10, Boringhieri, Torino.

5 "Crimes inexpliquables" i.e. the enigma of Edgar Allan Poe in M. Galzigna, La malattia morale. Alle origini della psichiatria moderna, Marsilio, Venezia, 1988, p. 273.

6 Among the significant definitions of terrorism:

- "Criminal Acts against the State with the determinated intention to create a state of panic and terror that taking place between particolar people or groups or the wider population";

- "a method that aims to create states of terror by means of violence, used by semi-clandestine groups or secret agents of particular states and with particular political aims or simply criminals. The criminal act is not directed towards single persons, as in political assassinations, but victims picked at random, victims of opportunities, or once symbolic victims have come to the target, with the primary intention of sending a message";

"a state of war, the dramatization of the worst kind of violence, unexpected, towards innocent victims, with the intention of creating a state of fear that extends beyond the victims involved". V. Mastronardi, G.B. Palermo, Il profilo criminologico. Dalla scena del crimine ai profili socio-psicologici, Giuffrè, Milano, 2005, p. 340.

A. Silke, Holy Warrior: Exploring the Psychological Processes of Jihadi Radicalization, European Journal of Criminology, 2008, 5, 99, doi: 10.1177/1477370807084226; R. Borum, Psychological Vulnerabilities and Propensities for Involvement in violent extremism, Behavioral Sciences and the Law, 2014, 32, 286-305, doi:10.1002/bsl.2110.

8 C. Lombroso, L'uomo delinquente, Quinta edizione, 1897, Bompiani, Milano, 2013, pp. 372 ss.

9 A. Raine, L'anatomia della violenza, Mondadori, Milano, 2016.

10 S. Baron-Cohen, La scienza del male. L'empatia e le origini della crudeltà, Raffaello Cortina Editore, Milano, 2012, p. 13.

11 S. Baron-Cohen, ibidem, p. 14.

12 G.B. Palermo, V. Mastronardi, "Il profilo criminologico. Dalla scena del crimine ai profili socio-psicologici" Giuffrè editore, Milano, 2005, p. 342. Per approfondimenti, V. Mastronardi, S. Leo, Terroristi, Newton \& Compton, Roma, 2005.

13 May I die together with the Philistines! " He bent over with all his strength and the house fell on the chiefs and all the population inside. They were more the dead that he caused with his death than he had killed in life ." "(The Holy Bible, Judges 16/27-30).

14 The Berserkir were bloody Viking warriors as well as pagan religious fanatics who lived between the seventh and twelfth centuries. who fought in the name of the God Odin, in a mental status of fury called berserksgangr. V. Samson, The Bersenkir. The warriors-beasts in ancient Scandinavia, from the age of Vendel to the Vikings (VI-XI century), Edizioni Settimo Sigillo, Rome, 2016. 
themselves an enemy ${ }^{15}$. Often behind the massacres by what are called "lone wolves", there is only apparently a religious or ideological reason, as the Mass Murder ${ }^{16}$ act as spokespersons for an ideology shared by a group of individuals, without however having a direct link with the association and using the Faith only as a pretext to realize their desire to kill himself and kill.

We may be led to believe the frustration is at the root of the evil, as claimed by numerous authors (John Dollard and Neal Elgar Miller), who, through the "theory of frustration"17, explain how the urge to act aggressively of the mankind is not instinctive, but it derives from the inability to overcome the obstacle that is interposed between the individual and the purpose that the same mankind wants to achieve and which causes the feeling of frustration. The theory, as formulated above, brings out the limit of the exclusive determinism of the relationship between frustration and aggression. In fact, there are many examples of non-violent reactions as response to episodes of frustration and aggressive behavior not determined by frustration.

An interesting fact is found in a study carried out by Prof. M. Sageman, psychiatrist of the University of Pennsylvania, about the terrorist phenomenon. Prof. Sageman has discovered, plotting federal documents and records of Islamic terrorists, which often the latter come from families in which there was no lack of instruction, neither education nor affection. Therefore, the debunked widespread idea in public opinion that terrorists are persons who are necessarily isolated on a social level, full of frustrations and belonging to disadvantaged classes. Miller himself, in $1941^{18}$, modified his theory of frustration, revising it in a probabilistic key and asserting that frustration can provoke different types of answer, one of which can be a form of aggressive response.

Apart from the phenomenon of terrorism, history has unfortunately offered many opportunities to reflect on the subject. The Holocaust ferocity perpetrated since the second half of the twentieth century by the Nazis in the concentration camps against the Jews and others "categories" of people considered "undesirable" by Hitler, leads us to wonder how people can get even to commit genocide. Hannah Arendt, a correspondent for the New Yorker weekly in Jerusalem, was responsible for studying, in particular, the behavior of Otto Adolf Eichmann, one of the commanders of the $\mathrm{SS}$, who played a decisive role in the extermination of the Jews. Mrs. Arendt, after following the 120 sessions of the Eichmann trial, decided to write "A Report on the banality of the Evil", translated in Italy with the emblematic title "The banality of evil"19. According to the author "the actions were monstrous, but whoever made them was almost normal, neither demonic nor monstrous" but ordinary men who respected and put into practice the orders received in a blind and chilling form of obedience; men "neither perverse nor sadistic, but were, and still are, terribly normal" 20 . Man's propensity to evil has also been studied through two experiments, which have shown how far people can go in hurting to their own kind. The first was carried out in 1961 by the psychologist Stanley Milgram²1 (inspired by the trial of Eichmann and the other military officers about the genocide of the Jews), to verify if the duty of obedience can push one person to harm another only in order to respect an order from an authority. The subjects chosen for the experiment were provided a machine equipped with various switches, with writings ranging from "light shock" to "dangerous shock" and with voltage indications from 15 to 450 volts, connected to an individual to be interviewed (scientist's accomplice). The task given to the examiners was to free a shock every time the interviewed person gave a wrong answer. Despite the interviewer's (simulate) pain screams, $65 \%$ of test subjects pressed a button connected to a shock that could potentially cause the interviewee's death. From this test Milgram deduced the existence in human behavior of a correlation between obedience to a figure, which is recognized as the referential, and the consequent of the moral non-responsibility ${ }^{22}$.

The other psychological experiment, called Stanford Prison Experiment, was conceived by Prof. Philip Zimbardo, of Stanford University, in 1971. The teacher selected twenty of his students, considered to be among the most balanced psychologically and asked them to play the role of wardens and "jailbirds", structuring the premises of the University as a prison institute. After just five days, the experiment was interrupted because the students who simulated the role of guard had begun to carry out an oppressive behavior towards the students with the role of prisoners, consisting of sexual humiliation and brutal physical violence. The circumstance of wearing guard uniforms or prisoners and of adhering to very specific prison rules had triggered a psychological process that would induce people to behave in ways that are not their own, but are generated by the influence of the meaning attributed to a given object or to a rule, in this case represented by the outfit. Prof. Zimbardo, taking up the theory of de-individuation by Gustave Le Bon, claimed that the individuals of a cohesive group, constituting a crowd, tend to lose personal identity, awareness, sense of responsibility, fueling the appearance of antisocial impulses.

From this experiment the scholar has drawn the conclusion that "the seeds of madness can be planted in anyone's garden" 23 and that

15 V. Mastronardi, M. Iandolo, Il Lupo Solitario: terrorismo ideologico - religioso nella società liquida, Revista URBE et IUS, Buenos Aires, Número 13, Invierno 2014; A. W. Kruglanski, M. J. Gelfand, J. J. Bélanger, A. Sheveland, M. Hetiarachchi, R. Gunaratna, The Psychology of Radicalization and Deradicalization: How Significance Quest Impacts Violent Extremism, in Advances in Political Psychology, Vol. 35, Suppl. 1, 2014, doi: 10.1111/pops.12163; V. Mastronardi, R. De Luca, I serial killer. Il volto segreto degli assassini seriali: chi sono e cosa pensano? Come e perché uccidono? La riabilitazione è possibile?, Newton \& Compton, Roma, 2009.

16 The Mass Murder kills or attempts to kill several people contextually and in the same place. According to V. Mastronardi and G. B. Palermo ("The criminological profile. From the crime scene to the socio-psychological profiles", Giuffrè, Milan, 2005) 3 people are needed; following, instead, the Federal Bureau needs four to be able to talk about Mass Murder (Crime Classification Manual, 1992). It is divided into two categories: Classic Mass Murder (or "the one who directs his own homicidal aggressiveness on the outside, to people unknown to him, but identified at that time as subjects belonging to an institution to be hit: society") and Family Mass Murder or homicidal mass murderer or extended suicide ("mass murderers who turn their fury towards their family, usually exterminated it"); $V$. Mastronardi, Manual for criminological operators and forensic psychopathologists, Giuffrè, Milan, 2012, pp. 420-422.

17 J. Dollard, N. E. Miller, L. W. Doob, L. H. Mowrer, R. R. Sears, Aggressive behavior always assumes a bouts of frustration and, conversely, the existence of frustration always leads to some form of aggression", Frustration and Aggression (1939), trad. It. Frustrazione ed aggressività, Editrice Universitaria, Firenze, 1967, p. 13.

18 E.N. Miller, The Frustration-Aggression Hypothesis, in Psychol Review, n. 48, 1941, pp. 337-342.

19 H. Arendt, La banalità del male. Eichmann a Gerusalemme, Feltrinelli, Milano, 1993.

20 H. Arendt, ibidem, p. 282.

21 American psychologist, professor at Harvard and Yale.

22 The experiment was revived in several countries; in particular, the social psychologist Daniel Bateson rewrote this experiment adding the possibility for the participant to be able to replace the person who was to take the shock after having informed him that the same was susceptible to electric shocks. The percentage was one in five who agreed to replace the interviewee. Cfr. I. Merzagora Betson, Colpevoli si nasce? Criminologia, determinismo, neuroscienze, op. cit., p. 67.

23 P. Zimbardo, The Lucifer Effect: Understanding How Good People Turn Evil, Random House, New York, 2007, trad. it., L'effetto Lucifero. Cattivi si diventa?, Raffaello Cortina, Milano, 2008, p. 368. 
"normal" people, without initial inclinations to sadism or brutality, can turn into individuals capable of brutal acts, as a consequence of institutional factors. The author attributed the tragic events of the Holocaust and the atrocities that occurred, for example, in Bosnia, in Rwanda, in Darfur, in Kosovo, to the so-called "Lucifer effect"24, that is the theory that even morally intact individuals can make cruel acts in certain situations.

From the considerations made so far, it is clear that human being behavior does not lend itself to simplistic explanations as it is determined by multiple factors (biological, psychological, environmental), as well as an unavoidable component of randomness. Human conduct is only partly conditioned by genetics, influenced by environmental and social factors, conditioned by the structure of brain circuits and neuronal networks, which contribute to the formation of emotions. It is necessary to accept the fact that our spasmodic search to find a scapegoat, that accepts in itself the evils and the sores of the human kind and that it furnishes univocal explanations, is devoted to be false.

Not necessarily a cruel act is symptomatic of a mental pathology of the subject who performs it and, therefore, we need to investigate when we are really facing a mentally disturbed subject, to assess whether or not to apply a criminal sanction to the latter.

\section{The Neuroscience and the Law}

Studies on the genesis of malice and crime have also been resumed in the last few years and developed thanks to neuroscientific studies on genetics, structure, development and physiological and pathological functioning of the central and peripheral nervous system, identifying brain anomalies and dysfunctions linked to the temporal and Libyan area, such as the hippocampus, the amygdala and the frontal lobe, which oversee the person's mental and behavioral expressions.

The need to give a logical explanation to human conduct, especially those characterized by an obscure charge of cruelty, it has always been at the center of studies, from the most varied disciplines.

Until a few decades ago, the human mind and actions were the prerogative of philosophy and psychology, but today thanks to scientific evolution, and in particular to the contribution of the structure, the encephalic functioning and the mental and decisional processes. The nineties of the last century have been called "the decade of the brain" 25 , precisely because of the increasing interest that the scientific community has dedicated to the study of cerebral functioning. The new techniques are considered by the pre-eminent doctrine to improve the rate of objectivity and scientificity of the appraisal in the process, as methods considered absolutely convincing ${ }^{26}$. Relevant voices of minority doctrine, on the other hand, tend to reduce the scientific value ${ }^{27}$ of these techniques.

The term neuroscience 28 "refers to a heterogeneous group of scientific disciplines, united by the objective of explaining how neuronal connections oversee the development of all human activities, not only those that occur in simple bodily movements, but also the most complex ones (the volition, emotions, even the formulation of moral judgments), traditionally attributed to the domination of the mind and considered inaccessible to the experimental investigation" 29 . In particular, among the Brain Imaging or neuroimaging techniques of the visualization of the brain, developed in the neuroscientific field, it is possible to distinguish between:

- Methods of structural visualization, which study the anatomy

of the brain, the characteristics of the tissues (e.g., quantity of gray or white substance) and the presence of pathological conditions (tumors, hemorrhages, infarcts);
- Methods of functional visualization, are useful for identifying the brain areas involved in a specific function, the activation sequence of the areas involved in a task, as well as the effects that certain neurological (injuries) and psychiatric pathologies (autism, schizophrenia) have on these areas.

Among the methods of structural visualization, the conventional radiography (which provides a static picture of the skull and its contents through the use of an x-ray beam) is worthy of note; the computerized tomography (TAC; the first computerassisted brain visualization technique, with which images of bone, brain tissue, cerebrospinal fluid are obtained, and intracerebral structures, such as, for example, it can be recognized thalamus, nucleus of the base, grey and white substance of the cerebral cortex and ventricles); the magnetic resonance imaging (MRI; used to obtain detailed images of the cerebral anatomy, exploiting the nuclear properties of certain atoms in the presence of magnetic fields).

Even more interesting are the evolutions made about the functional visualization methods and the use of so-called tomographic techniques of nuclear medicine, such as functional magnetic resonance imaging (fMRI), which deals with (using the BOLD, Blood Oxygenation Level Dependent, contrast, i.e. ratios of deoxyhemoglobin $\mathrm{Hbr} /$ oxyhemoglobin $\mathrm{HbO}_{2}$ in the nervous tissues), to measure hemodynamic blood volume responses, the cerebral flow and oxygenation of tissues indirect visualization technique of brain activity), which is based on the use of positrons emitting tracers, able to provide information on the metabolism of the brain at rest or during the performance of a given task.

The fMRI techniques show the encephalic areas (called "colored areas") which are activated when the subject undergoing to the test performs a specific task. Thanks to the use of these types of functional methods it was possible to determine which areas of the brain affect the human behavior and, in particular, on the cognitive functions of individuals.

The amygdala, for example, is a subcortical structure of the brain considered "a sentinel, an emotional computer of the brain" 30 , since (through non-invasive tests such as PET) it has been verified

24 P. Zimbardo, The Lucifer Effect: Understanding How Good People Turn Evil, ibidem.

25 L. Boella, Neuroetica. La morale prima della morale, Raffaello Cortina Editore, Milano, 2008.

26 I. Merzagora Betsos, Il colpevole è il cervello: imputabilità, neuroscienze, libero arbitrio: dalla teorizzazione alla realtà, in Riv. it. med. leg., 2011, p. 180

27 M. Bertolino, Il breve cammino del vizio di mente. Un ritorno al paradigma organicistico? in A. Santosuosso (a cura di), Le neuroscienze ed il diritto, Pavia, 2009, pp. 121 ss.

28 The term was originally coined by Schmitt in 1962, who, together with other scientists, set up a research group (Neuroscience Research Program- NRP) with the aim of eliminating the traditional disciplinary barriers that prevented researchers from collaborating in a common project.

29 C. Grandi, Neuroscienze e responsabilità penale. Nuove soluzioni per problemi antichi?, Giappichelli Editore, Torino, 2016, p. XI. For a definition of neuroscience see also L. Algieri, Neuroscienze e testimonianza della persona offesa, in Riv. It. Med. Leg., 33, 2012, p. 904: "Neurosciences are concerned with the study of the brain and the nervous system of living organisms at the molecular, biochemical and genetic levels. The purpose of neuroscience is to analyze the biological basis of mental and behavioral expressions of the animal and of man starting from the study of single nerve cells, neurons".

30 P. Pietrini, Responsabilmente: dai processi cerebrali al processo penale. Prospettive e limiti dell'approccio neuroscientifico, in AA.VV., La prova scientifica nel processo penale (a cura di De Cataldo Neuburger L.), Padova, 2007, pp. 325 ss. 
that it plays a decisive role in the planning of the act conscious and in the control of the individual's impulses.

By way of example, it is recalled that the "psycholepathy" (clinical category that has as its main symptom the pervasive nonobservance of the needs and rights of others) is associated with a malfunction of some areas of the brain, among which the amygdala, poor reactivity of so-called "Mirror neurons" 31 , which would allow us to anticipate and understand not only the motor acts and rational factors, but also the emotions of others ${ }^{32}$.

The goals achieved in recent years by neuroscientific studies would seem to confirm the reflections developed by the American physiologist Benjamin Libet $^{33}$, thanks to his experiments on free will conducted in $1977^{34}$.

In fact, already in the nineteenth century, eminent neuropsychologists ${ }^{35}$ had begun to study the correlation between brain and emotions, in particular, one of the most emblematic cases in the matter was that of Phineas Gage ${ }^{36}$, foreman of Vermont who in 1848 had a serious accident at work. During the construction of a railway, due to an inattention, the man was pierced by an iron bar of one meter in length and six kilos of weight, which went to stick in the skull of Gage, penetrating in the left cheekbone, passing from the left frontal lobe and coming out from the top of his head. The man, incredibly, survived the operation but after the incident his personality underwent remarkable change, turning him into an irreverent and irascible, vulgar and unreliable man. His skull and the piece of iron were kept at the Harvard Medical School and they have been recently studied by Professors Hanna and Damasio of the University of Iowa. The presence of lesions in the part of the pre-frontal cortex and in other areas of the brain has been ascertained that, in light of the acquisitions of neuroscience, identify themselves as areas responsible for the emotional regulation. Therefore, the bar caused some cerebral damages in Gabe, which led to the change of the personality of the man and his loss of control of primary impulses.

Another interesting case is the most recent one in 1999, in Virginia (USA) concerning a teacher and father of a family, always characterized by irreproachable behavior, which suddenly, due to a tumor that compressed the right side of the frontal lobe, began to implement sexually harsh behavior towards the young stepdaughter. The removal of the malignancy has determined the cessation of pedophile impulses by the man, thus demonstrating a correlation between that specific encephalic area and the ability to control the impulses.

The useful fields of application of neurosciences are varied. We are now witnessing the emergence of neuro-marketing techniques (a discipline that, through the use of neuroscientific methods, studies the most effective communication channels on purchasing decisionmaking processes), to use the neuroscience for therapeutic purposes (to relieve or treat disorders of the nervous system ${ }^{37}$ ), until the application of neuroscientific techniques in the field of design ${ }^{38}$. Neuroscientific research finds more and more space within the debate not only neuro-ethical ${ }^{39}$, but also juridical. In fact, in the legal field, the use of neuroscience opens multiple scenarios. Within the criminal process the possible application areas, in which neurosciences can be useful, are mainly two: the verification of the reliability of the declarative tests, through suitable methods to assess the truthfulness or not of the answers and the use of neuro-scientific appraisals to ascertain the existence of a mental defect.

Regarding the assessment of the truthfulness of a testimony through neuroimaging techniques, it can be ascertained when a person lies, verifying if at the moment when the question is addressed to the subject its lateral frontal cortex (called DLPFC develops a false but credible answer) and its anterior cingulate cortex (ACC, which brakes the truthful answer replaces it with the lie) are activated.

Today it is, in fact, possible through magnetic resonance techniques such as fMRI and PET, to verify in which areas of the brain there is greater flow of blood, i.e. greater expenditure of energy and, therefore, where there is neuronal activity. These modern techniques, much more reliable than the old polygraph ${ }^{40}$ or

31 They are a particular category of neurons identified by the research group of the University of Parma directed by Professor Giacomo Rizzolatti, which allow us to empathize with our fellow mankind, making us able to understand the situation and the emotions that another person is experiencing. G Rizzolatti, C. Sinigaglia, So quel che fai, il cervello che agisce ed i neuroni specchio, R. Cortina, Editore, Milano, 2006.

32 S. Mazzaglia, Nuova teoria degli anti-neuroni e anti-neuroni specchio. L'anti-empatia, l'anti-risonanza, l'anti-rispecchiamento, le antiemozioni tra scienze dell'educazione, pedagogia visiva, neuroscienze, criminologia, filosofia, diritto penale, Edizioni Univ. Romane, 2015. C. Raighero, Neuroni specchio, Bologna, 2010. D. Donelli - M. Rizzato, Io sono il tuo specchio. Neuroni specchio ed empatia, Torino, 2011.

33 B. Bottalico, Il diritto penale e le neuroscienze, quali possibilità di dialogo?, online su www.academia.edu; cfr. M. Casellato, D. La Muscatella, S. Lionetti, La valutazione di responsabilità del soggetto autore del reato. L'evoluzione delle neuroscienze e l'impatto sul sistema penale delle nuove metodologie scientifiche, in Rivista penale, n. 3, 2014 p. 249.

34 In 1977 the American neurophysiologist and psychologist Benjamin Libet (1916-2007), gave rise to his experiment, in order to establish if there was a temporal difference between the beginning of the PPM (potential motor readiness, detectable by the measurement of electrical activity in certain parts of the brain when it is necessary to make a movement) and the realization by the subject of wanting to perform that action. Through the use of the electroencephalograph (EEG) and the electromyograph (EMG) to measure the electrical activity of the brain and muscles, and a specially modified oscilloscope, he ascertained that between the preparation of the movement and the awareness of the same one is recorded a difference of 0.35 seconds. Libet showed, therefore, that the brain is predisposed to the movement before the subject realizes the will to do it, B. Libet, Mind Time. The Temporal Factor in Consciousness, Harvard University Press, 2004.

35 A. Bianchi, G. Gulotta, G. Sartori, Manuale di neuroscienze forensi, Giuffrè, Milano, 2009, p. XIII.

36 To deepe: H. Damasio, T. Grabowski, R. Frank, A. M. Galaburda e A. R. Damasio, The return of Phineas Gage: clues about the brain from the skull of a famous patient, in Science, vol. 264, pp 1102-1105; For the description: O. Di Giovine, in Un diritto penale empatico? Diritto penale, bioetica e neuroetica, p. 131-132; G. Zara, Neurocriminologia e giustizia penale, in Cassazione Penale 2/2013, p. 827; I. Merzagora Betsos, Colpevoli si nasce? Criminologia, determinismo, neuroscienze, Raffaello Cortina Editore, Milano, 2012.

37 Whether modulating neurophysiological functions, e.g. deep brain stimulation in patients with Parkinson's disease; and reintegrating motor functions, e.g. brain-computer interfaces for people with severe paralysis or neuro-rehabilitation equipment for patients with cerebral stroke; both by returning sensory functions, for example cochlear or retinal implants.

38 IULM University and Triennale di Milano, as part of the XXI International Triennial of Milan, which includes exhibitions and events dedicated to the theme "Design after Design", have launched the project "Exhibition Design, Neuroscience and Gender Difference", thanks to which it will be possible to measure and "radiograph", through neuroscientific techniques, the emotional reactions of visitors to the sight of selected images of works of the exhibition and to evaluate the differences in perceptions in men and women to aesthetic stimulation.

39 The term became known, especially after 2002, with the San Francisco Neuroethics conference: Mapping the Fields. The advent of neuroscience has involved the development of several neologisms including "neurodiritto", "neurofilosofia", "neuroestetica” and others. A. Lavazza, G. Sartori (edited by), Neuroetica. Scienze del cervello, filosofia e libero arbitrio, il Mulino, Bologna, 2011.

40 The polygraph with "Control Question Test", so-called "Older Generation" truth machine is a tool that can detect autonomous physiological activations (such as, for example, heartbeat, blood pressure, breathing, sweating), related to some critical questions and a polygraph. It is unsuitable for use in criminal proceedings, as it is based on the emotional states of the subject subjected to the test, generating unreliable results and damaging the moral freedom of the person. 
the thermography ${ }^{41}$, are peacefully acquired in the scientific community and have a much more reliable scientific coverage law, as it is demonstrated the existence of a close relationship between the neuronal activation of certain areas of the brain and the formulation of a lie. Furthermore, there is no violation of the moral freedom $^{42}$ of the subject, because the person is not placed in a situation of high stress and it is non-invasive examinations that, therefore (beyond the need to improve these techniques adapting them to the individual who it is submitted to $\mathrm{it}^{43}$ ), could have a great usefulness for the trial purposes. Modern technologies could provide a contribution in the courtrooms, even for the purpose of finding "traces of memory" of the crime (memory detection) in the mind of the subject interviewed, through the use of the Polygraph with Guilty Knowledge Test (GKT) ${ }^{44}$, of the Brain Fingerprinting ${ }^{45}$ or the $\mathrm{IAT}^{46}$. In the even more interesting juridical sphere, the use of neuroscience appears in the investigation of the capacity to understand and discern of the accused subject.

Lately, many studies of molecular biology and behavioral genetics have been carried out aimed at identifying respectively the human genome and the influence of the genetic heritage on human behavior and personality ${ }^{47}$. In particular, there is a correlation between a particular type of genes, such as SLC6A4 and MAOA ${ }^{48}$, and the crime, in the sense that the subjects who have them, have a lower capacity to control aggressive impulses and, therefore, have a deterministic role in the development of probable criminal and violent abilities. From these scientific insights, the jurisprudence has recently decided to open the doors of the courtrooms to the neurosciences, to facilitate the assessment of the capacity of

41 Technique able to measure the temperature variations on a person's face and used with the same CQT method of the polygraph and, therefore, endowed with limited functionality and reliability as the person is extorted through an invasive form of interrogation and stressing the subject interviewed.

42 L. Sammicheli, A. Forza, L. De Cataldo Neuburger, Libertà morale e ricerca processuale della verità: metodiche neuroscientifiche, in Manuale di Neuroscienze Forensi, a cura di Bianchi, Gulotta, Sartori, Giuffrè Editore, 2009, p. 244.

43 G. Sartori-S. Agosta, Menzogna, cervello e lie detection, Manuale di neuroscienze forensi, Giuffrè Editore, 2009, pp. 170-171.

44 Some images are shown to the subject or questions related to the crime are made; some relevant for the purpose of identifying the dynamics and the manager and others irrelevant. The subject not involved in the offense will tend to have very similar physiological reactions for each question, regardless of the relevance or not with the crime, as it is not able to distinguish the relevant questions from those irrelevant, the guilty subject, instead, manifests of physiological variations in front of questions or images concerning the crime. D.T. LYKKEN, The GSR in the detection of guilt, in Journal of Applied Psychology, 43, 1959, pp. 385-388; and also, by the same author, Psychology and the lie detector industry, in American Psychologists, 29, 1974, pp. 725-739.

45 The system is very similar to that of the GKT: to the subject is, in fact, asked questions or shown images, some of which are critical (related to the crime, and which only the culprit can know), others irrelevant. With this test, instead of assessing physiological changes (such as heartbeat or blood pressure), responses are recorded in brain activity following questions or viewing images relevant to the investigation of the crime.

46 It is an indirect measuring instrument which, based on reaction times in the answers, it establishes the association between concepts; when the truth is told, the answer is immediate and, therefore, the reaction times will be quick, in case of lying, instead of, more complex cognitive processes are implemented as there is no immediate association between the concepts and consequently the times of reaction will be longer.

47 G. Sartori, D. Rigoni, L. Sammicheli, L'orologio di Libet e la responsabilità penale, in Gulotta-Curci (a cura di), Mente, società e diritto, Milano, 2010, p. 265 ss. understanding and the intention of the perpetrators of a crime affected by vices of mind.

Neurosciences, thanks to their ability to detect injuries or dysfunctions related to pathological behavior ${ }^{49}$, could make a valuable contribution to the judge in providing him with further and relevant criteria, to evaluate the capacity to understand and discern of the accused ${ }^{50}$. As also noted by the National Bioethics Committee, "considering the discovery of cerebral areas correlated with the development of impulsive and violent behaviors, it should be recognized that neurosciences can help to detect brain dysfunctions that hinder the fulfillment of certain functions or which contribute to disturbed outcomes" 51 . The discovery of these dysfunctions, if in the medical field can suggest the implementation of certain therapies, in the process of criminal proceedings could provide valuable input in the assessment of the imputability ${ }^{52}$.

In the judicial field, however, the data obtained from the neuroscientific investigation cannot be used to base the evaluation of imputability in an automatic way, but this must be first interpreted by the expert (for example, by the behavioral neurologist or the clinical neuropsychologist) and then by the judge ${ }^{53}$, who must contextualize it, in light of the other procedural findings, and assess whether the illness has a real etiological link with the crime committed ${ }^{54}$. One of the basic problems arising from the application in the field of neuroscience concerns the compatibility of these techniques with the article 188 of c.p.p. (the Italian Penal Code), which protects the moral freedom ${ }^{55}$ of the subject in taking evidence.

Article 188 (and article 64, paragraph 2) of the Italian Penal Code provides for the prohibition of the use of methodologies to

48 C. Fabbri, L. Cimino, A. Serretti, Genetics of impulsive-aggressive behavior: ready for application in forensic psychiatry? (Genetica dei comportamenti impulsivo-aggressivi: possibile applicazione in psichiatria forense?), Rassegna Italiana di Criminologia, anno VI, n. 1, 2013.

49 Behavioral or performance changes are classified as "pathological" - with a risk of error statistically defined with appropriate procedures with reference to behavior and performance, quantitatively measured by tests, scales and structured interviews of an adequate number of healthy subjects, comparable for the socio-demographic variables (for example, age, sex, education) to the subject under examination; on the verge, E. Capitani, M. Laiacona, The evaluation of experimental data in neuropsychology, in G. Denes, L. Pizzamiglio (a cura di), Handbook of clinical and experimental neuropsychology, Hove, Sussex, Psychology Press, 1999, pp. 57-68.

50 C. Grandi, Sui rapporti tra neuroscienze e diritto penale, in Riv. it. dir. proc. pen., 2014, p. 1289.

51 Presidency of the Council of Ministers, Opinion of the National Bioethics Committee, Neurosciences and human experiments: bioethical observations, $17^{\text {th }}$ December 2010, http://www.palazzochigi.it/bioetica/ pareri.html

52 from a study conducted on sixty-six ex-combatants of a paramilitary terrorist group, at the end of which a resemblance between the deficits in the moral judgment of patients suffering from front-temporal dementia and the pattern observed in terrorists would emerge, in S. Baez, E. Herrera, A. M. Garcìa, F. Manes, L. Young, A. Ibáñez, Outcome-oriented moral evaluation in terrorists, in Nature Human Behaviour 1, 1-8, 2017.

53 They highlighted this profile: U. Fornari, A. Pennati, The scientific method in psychiatry and forensic psychology (part 1), Brainfactor Brain and Neuroscience, 19 April 2011: "the Neuropsychology can offer a valid help in the search of answers and construction of clinical frameworks and assessment procedures richer, more articulate and more based on objectivity and, therefore, on the evidence of data, but the clinic once again remains sovereign in the interpretation and evaluation of the same".

54 M. Bertolino, Prove neuro-psicologiche di verità penale, in Dir. pen. cont., 8 january 2013 , p. 17 , which enhances the indications of the famous Cass. United Sect., 25 january 2005, Raso.

55 Moral liberty means "the integrity of the person's faculty of proof to determine freely with respect to stimuli", P. Tonini, La prova penale, Cedam, 2000, p. 186. 
influence the freedom of self-determination. Moral freedom is also protected by art. 3 of the European Convention for the Protection of Human Rights and Fundamental Freedoms, which establishes the prohibition of subjecting anyone to torture or inhuman treatment, and art. 7 of the International Covenant on Civil and Political Rights, which prohibits the compulsorily subjecting a person to medical and or scientific experiments. The Constitutional Court ${ }^{56}$ has clarified that the article 188 must be applied not only to the declarative tests, but also to personal surveys.

The use of functional neuroimaging techniques (fMRI and PET), in the light of jurisprudential openings ${ }^{57}$ seems to be granted because, through the use of these new methods, the evaluation and mnemonics faculties of the subject are left intact and the same is not subjected to any form of coercion; in fact, the use of headphones or electrodes does not compromise his freedom to determine freely.

Another problematic aspect of the use of neuroscience is the risk of falling into a dangerous determinism, which automatically assigns the responsibility of a fact on the basis of chemical-electrical detections of neurons. The paradox that drags technological and scientific evolution is that, "if the tools of neuroimaging are based on the identification of the transmission of electric discharges (a physical phenomenon), which in turn are the result of the combustion of glucose and oxygen (chemical phenomenon), then the neurological reductionism must, in turn, be reduced to physical and chemical phenomena. Then the culprit is not even the brain, the culprit is the molecule" 58 . A distorted and excessive use of these new techniques can therefore have dangerous repercussions, both in the criminal justice field ${ }^{59}$, and that in an ethical-anthropological perspective ${ }^{60}$. It is lawful to resort to the use of new neuroscientific inputs, to reduce more and more the approximation in the success of a real reconstruction of a historical fact and even more to investigate the criminal liability of an individual, in relation to a crime, without, however, falling into dangerous automatisms, capable of assigning to science a certain and unavoidable test value.

It is therefore necessary to open up to scientific evolution, but always taking care to avoid that individual guarantees find a restriction, in the face of scientific progress, respecting the protocols that guarantee the successful outcome of the probation, not violating the freedom of self-determination of the subject subjected to scientific examinations. The imputability is a legal concept, relating to the branch of criminal law, which has always been the protagonist of doctrinal and jurisprudential debates. It plays a fundamental role in our legal system, since it is connected to the principle of guilt, as established by the Constitution in art. 27, which constitutes a fundamental defense of the person, as it ensures that nobody can respond to a fact of crime of which it is not concretely able to grasp its social non-value. In this regard, the article 85 of our penal code states that "no one can be punished for a fact established by law as a crime if, at the time he committed it, it was not imputable". Those who have the capacity to understand and discern are imputable".

Our code covers the approach chosen by the creators of the previous Zanardelli Code, as also in our current code to articles 88 and 89 c.p. (Italian criminal code) the concept of infirmity remains without any specification.

In particular, articles 88 and 89 , sanctioning the total defect of mind, states that "It is not responsible who, at the time when he/she committed the fact, he/she was out of infirmity, in this state of mind to exclude the capacity to understand and discern", the Art 89 deals, instead, with the partial defect of mind, establishing that "Who, at the time in which he/she has committed the fact, he/she was, for infirmity, in such a state of mind to diminish greatly, without excluding it, the capacity to understand and discern, he/she responds to the crime committed, but the penalty has decreased". From article 88, in particular, a point of continuity emerges with the previous code, represented by the adoption of a mixed-type judgment of imputability. In fact, to exclude the imputability of an individual, it is not only necessary that he/she is affected by an illness but also that this has had a concrete impact on his capacity to understand and discern.

The problem related to the attribution of a meaning determined to the concept of illness is criminally relevant, and remains open and still under investigation. The vice of mind presents itself as a decidedly complex institute, both for the difficulty of delineating its boundaries and for the dimension of its concrete assessment, through the use of different disciplines, such as the legal science, the psychology, the psychiatry, which often present different and difficult reconcile visions.

There are numerous changes in the notion of mental illness on the part of the psychiatric science.

In the psychiatry field, the approach to the study of mental illness, affirmed since the end of the 1700s with the advent of the Enlightenment, it has been the so-called biological-organicist one for which "mental illness is defined as a physical disease of the central nervous system" 61 and the only relevant mental disability for the purpose of recognition of the total or partial defect of mind is for articles 88 and 89 c.p., it is dependant on the illness in the strict sense or "this medical-legal dependent on a serious pathological state that involves a degeneration of the intellectual or volitional sphere of the person acting" 62

Within the movement several subsets of ideas differed. The first orientation considered the mental illnesses of real diseases of the brain or of the nervous system, but necessarily having an organic or biological origin. The second orientation, whose paternity is attributable to Kraepelin ${ }^{63}$, is defined as a nosographic and he

56 Corte Costituzionale, 27 june 1996, n. 238 in www.cortecostituzionale.it

57 Corte d'Assise di Appello of Trieste, 1st october 2009, n. 5, in Riv. Pen., 2010; G.I.P. of Como, 20 may 2011, n. 536, Albertani, est. Lo Gatto, in Rivista, 15 th february 2012, with note of M. T. Collica, Il riconoscimento del ruolo delle neuroscienze nel giudizio di imputabilità. This is a case that has immediately attracted the attention of penal doctrine. On this topic, the comments of A. Corda, Riflessioni sul rapporto tra neuroscienze ed imputabilità nel prisma della dimensione processuale, in Criminalia, 2012, pp. 509 ss.; D. Terracina, Neuroscienze: lo studio della morfologia del cervello determinante nello stabilire il vizio parziale di mente, in Guida al diritto, n. 5,2012 , pp. 63 ss.

58 I. Merzagora Betsos, Colpevoli si nasce? Criminologia, determinismo, neuroscienze, op. cit., p. 85.

59 Barbieri observes, citing the words of Aversa at the congress of Arona, "Psychiatry and philosophy of the mind", as, "in criminal law, moreover, we must never forget that any discourse or method claims to objectivize the psychic, cannot remove the fact that it is psychic discourse itself ", so "any claim to objectively found a science that tells us what the psychic is, can only be partial, if it does not take into account the paradoxical situation that is determined, that is a substantial and paradoxical identity of the subject and of the object of the research ". (C. Barbieri, The neuroimaging in the medical - criminal field: some critical reflections, in $M G$ Ruberto, C. Barbieri, The future between us Ethical, legal and medicolegal aspects of neuro-ethical, Franco Angeli, Milan, 2011, pp. 15-31.

60 I. Merzagora Bestos, Colpevoli si nasce? Criminologia, determinismo, neuroscienze, op. cit., p. 85.

61 M. Bertolino, La crisi del concetto di imputabilità, in Diritto penale in trasformazione, Milano, 1985, p. 237.

62 Cass., Sez. I, 25 marzo 2004, n. 16940, Foro.it, Rep. 2004, voce Imputabilità, n. 10.

63 Emil Kraepelin (Neustrelitz 1856 - Munich 1926) German neuropsychiatrist and psychologist considered the greatest exponent of the clinical-nosographic movement and known for having founded in 1917 the famous Institute of psychiatric research, the present Max-Planck-Institut für Psychiatrie. 
classifies the specific models of infirmity with the respective symptomatology, so that a mental disorder can be traced back to a mental illness only if it is possible to place it nosographically in the expected categories, such as psychosis, the pathological conditions of organic origin, with the exclusion of neuroses, of psychopathies, of sexual deviations and of transient psychopathological disorders and, in any case, of all those psychic abnormalities not belonging to a specific type of illness classified ${ }^{64}$.

The third "under" movement is the one presented by the psychiatrist Jasper, which is based on the observation of the experience of each patient ${ }^{65}$, in order to detect the possible presence of a morbid process that establishes the mental illness, regardless of the reconditioning of the same to a determined a nosographic category. In the early 1900 s, within the case study of the concept of infirmity, the interest began to shift from the biological factors to the psyche of the person and a new psychological vision was affirmed for which the internal conflicts of a subject result in relevant mental illnesses for the purpose of imputability, when the disharmony of the psychic apparatus leads the person acting to consider more relevant his own unconscious reality than the external reality, because of the conflict that occurs between the structures of the personality ${ }^{66}$ of the subject.

According to this approach, regardless of the specifically classifiable mental alterations, any morbid disturbance of a psychic nature (including affective disorders, neuroses and psychopathies) it is evaluated not in relation to the organic-cerebral assessment of the disease, but in relationship to the actual impact on the capacity to understand and discern in the concrete case. Around the 70s of the last century, the so-called sociological paradigm takes hold, which denies the psychopathological or the organic nature of mental illness, stating that mental illness is a psychological disorder of social origin and develops due to inadequate conditions in the environment in which the subject lives.

The Modern Psychiatry is now inclined to implement a mixed model, which tends to conceive mental illness in the light of an integrated bio-psycho-social vision ${ }^{67}$. The Modern Science rejects a mono-causal etiological view of mental illness and agrees that in terms of both origin and course, mental illness must be studied in the light of a broader perspective, considering all the variables, biological, psychological, social, relational, which lead to an alteration of the psycho-physical abilities of the person acting, relevant to the judgment of imputability.

It follows that the concept of "mental infirmity" within the criminal law must be understood in a broader sense than that of psychiatric "mental illness", so much so as to be able to recognize even a mere personality disorder a relevance, when make sure the incidence in the capacity to understand and discern of the subject. In the courtrooms of justice, in fact, we have witnessed an interesting evolution of the interpretation of the concept of a relevant criminally mental disorder, for the purpose of evaluating the capacity to understand and discern of the offender.

In the past, the jurisprudence covering the biological-organic medical paradigm of the mental infirmity, tended to recognize the vice of mind only subordinately to the ascertainment of anatomo-functional alterations of the psychic sphere and clinically ascertainable or, in any case, only mental illnesses, in the narrow sense, "nosographically" delineated, excluding that the psychic abnormalities, like the neuroses or the psychopathies, could assume some importance in the judgment of imputability of the accused. The judges of legitimacy stated, consequently, that "infirmity must always depend on a pathological cause, such as to alter the processes of intelligence or will [...]. In this notion, therefore, not only all the anomalies of the personality or of the character or of the feeling can be understood, but also the neuropsychoses or psychoneuroses, which are diseases of the nervous system and have no anatomical bases [...], i.e. lacking of organic substrate and without organ injuries" $" 68$.

The jurisprudence initially believed that the relevant criminally mental illness could only be "a morbid alteration, however classifiable in the psychiatric field" and that "the capacity to understand and discern must be profoundly vitiated by a mental illness [...] which must depend on a pathological alteration settled permanently in the subject. Therefore, only the mental illness having a pathological root based on a morbid cause can exclude or reduce (...) the imputability ${ }^{69}$.

Consistent with the evolution of an extensive and receptive interpretation of the psychological paradigm, jurisprudence has also begun to broaden the concept of the mental illness, stating that it also includes the transient psychic disturbance, "provided that it concretely impacts on the capacity to understand and discern of the subject, so that any morbid situation, even if not clinically definable, is able to configure the mental defect" 70 .

The vision of the psychic disorder as a certain medically verifiable and documentable disease left, to "evaluate certain psychopathic deviations in their exact range", keeping in mind "the actual relationship between the type of abnormality found and the determinism of the criminal action committed"71, It follows that the mere personality disorders are no longer excluded a priori, but we proceed to evaluate the actual impact of the same on the capacity to understand and discern of the subject.

With the emergence of the modern psychiatric science, also the jurisprudential view has increasingly been adapted to an integrated model of the mental illness, which considers all the biological, psychological, social and relational variables that come into play in the determinism of the disease, accepting an elastic concept of infirmity, able to extend to include not only the mental illnesses classified medically, but also personality disorders.

In particular, with the judgment of 25 January 2005 n. 9163, known as the Raso sentence, the Court of Cassation definitively sanctioned that "even personality disorders, such as those caused by neuroses and psychopathies, they can constitute a suitable cause to exclude or greatly diminish, in an autonomous and specific way, the capacity to understand and discern of a subject acting for the purposes of articles 88 and 89 c.p., provided that they are of consistency, relevance, gravity and intensity such as to actually affect the same; conversely, for the purposes of imputability, the other "characteristic anomalies" and the "emotional and passionate states", which do not cover the aforementioned characteristics of incisiveness on the capacity of self-determination of the acting

64 M.T. Collica, op. cit., p. 47.

65 M. Bertolino, La crisi del concetto di imputabilità, op. cit., p. 240.

66 Freud identifies three psychic places (Topoi): the Es, the ego and the superego; the Es represents the psychic structure governed by the principle of the pleasure, the unconscious, the impersonal, devoid of logic and morality and seat of the instinctual energies, the ego represents the interface between the external world and the internal world, guided by the principle of reality and tents to assert the influence of the external world on the Es and its intentions; the Super-ego represents the internal moral conscience, where the social prohibitions reside and the objections that regulate the passage from the instincts from the Es to the Ego; Freud S., L'Io e l'Es, (1922), in Opere, vol. IX, Boringhieri, Torino, 2002, pp. 471-520.

67 M. Bertolino, L'imputabilità ed il vizio di mente nel sistema penale, Giuffrè Editore, Milano, 1990, p. 633.

68 Cass. Pen., 23rd october 1978, n. 4795, in Giust. pen., 1979, II, p. 406.

69 Cass., Sez. V, 16th july 1981, n. 4646, in Giust. pen., 1982, II, p. 333.

70 Cass., Sez. I, 26th november 1986, n. 866, in Cass. pen., 1990, p. 1039.

71 Cass. Sez. I, 2 july 1990, n. 313, in Giust. pen., 1991, p. 301. 
subject; it is also necessary that between the mental disorder and the crime there is an etiologic link, which allows to consider the second causally determined by the first". The judgment, through the use of a literal-systematic argument, has found that the notion of "infirmity", dictated by articles 88 and 89 c.p., it does not coincide with the concept of medical illness, which considers relevant mental alterations classified and ascertained on an organic-cerebral basis, but broader, including also the psychologic anomalies not framed nosographically (for example, psychoses) coming to recognize the relevance of personality disorders.

Moreover, the aforementioned ruling of the United Sections has finally taken a clear position on the methodology for ascertaining the defendant's mental illness, choosing a mixed-type of the judgment of imputability, on the basis of which it is necessary not only to ascertain the existence and the gravity of a possible mental disorder in the subject, but also proceed to the verification that this disorder has concretely affected his capacity to understand and discern. The abovementioned sentence, placing itself in line with the decisive rulings of the Constitutional Court n. 364 and n. 1085 of 1988, which recognized the imperative role of the principle of guilt within the judgment on the imputability of the person acting, establishes that it is not only necessary to carry out a qualitative (type of disorder) and qualitative assessment (intensity and severity of the disorder), but also to verify the existence of a causal link between this disorder and the type of crime committed.

The Supreme Court, as regards the assessment of mental illness in relation to the imputability, demonstrates, therefore, to share the psychopathological-normative address, which is not limited to punish automatically those individual suffering of nosographically defined diseases (purely psychopathology method), or to carry out an assessment of the capacity to understand and discern regardless of the assessment of a psychic illness (exclusively normative method), but split the judgment on imputability in two phases: on the one hand it proceeds to an assessment of gravity and of the relevance of the psychic disorder and, on the other hand, it verifies the actual relevance of the illness for the purpose of the capacity to understand and discern of the subject acting at the moment of the act.

To carry out this complex type of appreciation during the trial, the judge will have to investigate, as well as on the intensity of the mental illness of the person acting, also on the criminogenesis and on the criminodynamics of the crime, to verify the actual relationship of the psychic disorder with the specific fact. When this involves a further investigation of the reasons that led the criminal, assessing the degree of lucidity and guilt of the person at the time of the crime, analyzing his behavior before and after the fact, as well as his capacity to understand the meaning of their own behavior and the possibility of predicting their consequences. The Court has specified that, to grant the insanity to the person acting, "must, therefore, be a disorder suitable to determine (and that has in fact determined) a situation of uncontrollable and unmanageable psychic attitude (totally or in serious measure), which blamelessly makes the person acting unable to exercise the due control of his actions, and consequently direct them, to perceive the social disvalue of the fact, of autonomously, freely, self-determination".

\section{Legislation: The Orlando Reform and the crystallization of doctrinal and jurisprudential landings in matters of mental illness}

At the conclusion of a complex parliamentary procedure, on 4 July 2017, the law n. 103 of 23 June 2017, so-called Orlando
Reform, with amendments to the Criminal Code, the Criminal Procedure Code and the Prison System, which came into force on 3 August 2017.

The law, which introduced important changes in the Criminal Law, both in terms of substantive Law and that of Procedural Law, consists of a single article of ninety-five paragraphs, with rules immediately effective and others subject of specific delegations, which must be implemented by the Government through a series of Legislative Decrees, based on the principles and criteria of the directive dictated by the provision. The Reform, in addition to providing changes concerning, for example, the extinction of crimes as a result of remedial conduct, the regulation of the statute of limitations and to dispose of empowerment to the Government on the matter of certain crimes, personal security measures, news concerning the Penitentiary System and the Regulation of Appeals, also it deals with the issue of imputability, in particular with reference to the concept of insanity. In particular, the art. 1, paragraph 16, letter c) of the Legislative Reform delegates the Government to provide for the "revision of the definitive model of the infirmity, through the provision of clauses able to attribute relevance, in accordance with established scientific positions, to personality disorders".

The Orlando Reform has taken steps to fill a gap in our Legal System, which for some time required an intervention by the legislator. In fact, before this Reform, the regulatory framework in the matter of defect of mind was completely unsatisfactory, since, as mentioned, our Criminal Code limits itself to establishing that "It is not responsible who, at the time he committed the fact was, due to illness, in such a state of mind to exclude the capacity to understand or to discern" (Art. 88 c.p.) and "Who, at the moment in which he/she committed the act, was by illness, in such a state of mind to be greatly diminished, without excluding it, the capacity to understand or discern, he/she responds to the crime committed, but the penalty is diminished "(Art. 89 c.p.).

Therefore, it is established that the "infirmity", which excludes the application of the penalty or which involves its reduction, it is only the one suitable to exclude or, in any case, significantly diminish the capacity to understand and discern of the person acting, without however being given any definition of the concept of infirmity. For some time, the formulation of a revision project on the subject of mental defects, relevant in order to the imputability was hoped, hence also in light of the numerous theoretical formulations coming from the psychiatric field, the jurisprudential approaches and the relevant neuroscientific contributions following in the last years. The reference of the law to "personality disorders" represents the crystallization of the paradigm enshrined in the jurisprudence, and in particular in the aforementioned Raso judgment of the United Sections of the Supreme Court, concerning the relevance, for the purposes of criminal imputability, also of serious personality disorders, as long as they might occur with a high degree of intensity and they have such as to significantly affect on the functioning of the intellectual and volitional mechanisms of the person acting. Therefore, the task of revising the concept of "infirmity" is delegated to the Government, in order to facilitate the judge in his task of assessing the intensity and relevance of the mental disorder of the offender, as well as the etiological nexus of the latter with the specific criminal action. The awareness of the plurality of factors has gradually increased, not only endogenous but also exogenous, which can determine the onset of mental disorders.

The evolution in the matter has led to believe that for the purpose of recognizing the total or partial defect of mind, also "serious personality disorders", with the exclusion of merely alterations and deviations of such a character type, linked to the 
character of the subject and such as not to affect his capacity of selfdetermination and emotional and passionate states, except that the latter do not fit, exceptionally, for their specific peculiarities, within a broader framework of infirmities.

The position of the legislator, aimed at recognizing a broad scope of the concept of infirmity, consistent with the evolution of the studies on the subject, does not deprive the judge of his delicate task of double assessment of the psychic disorder of the subject in terms of intensity of the infirmity, in relation to the capacity to understand and discern, as well as the analysis of the causal link between the psychic disorder and the actual fact of crime. The judge, in fact, cannot completely delegate to the expert the determination of the assumptions of the judgment of imputability, being such determination also characterized by evaluative-normative moments, but he/she may ask the expert to ascertain, also through the use of avant-garde sciences, if the accused in the act of acting was able to understand and discern or if the intensity of the psychic disturbance has invalidated his intellectual and volitional capacities. The task of the delegated legislator will therefore be to take as a starting point the latest jurisprudential and doctrinal approaches and give space to a broader concept of the infirmity, compared to that of the mental illness, avoiding that they end up being confused with the disorders of personality the simple character anomalies or behavioral quirks, causing an abuse of the exclusion of the imputability in subjects deserving to be punished for being able to understand and discern at the time of the crime. The Government will hence have the difficult task of providing suitable indications and normative parameters useful for the evaluation of the judge and his collaborators about the severity of the psychic and functional disorders to formulate valid criteria in order to ascertain the causal link between the infirmity and imputability.

The reform measures do not seem obvious, in fact, although an intervention by the legislator on the matter is necessary, in consideration of the inadequacy of our code with respect to the evolution of psychiatric-forensic studies in terms of infirmity, it should be noted that all it is now not possible to determine with certainty the actual alteration of reality by an accused, in relation to his own psychic disorder. On account of the inevitable uncertainty of the subject of the modification of the psychic abilities of a subject, part of the doctrine considers preferable legislative solutions tending to refrain from providing too stricter parameters and overly specific definitions.

It will be necessary, therefore, that the Orlando Reform is limited to guaranteeing the right place to judge about the imputability of the offender, providing parameters that are consistent with the theoretical-scientific developments and the legal sciences but which, at the same time, prevent the judicial apparatus to excessively enlarge the concept of "infirmity" to subjects who acted with awareness and will, despite the presence of a psychic disorder.

\section{The malice in blood crimes: Experimental approach}

A practical demonstration of the theoretical principles illustrated above, aimed at debunking the false myth of "criminal madness" and of the automatic association of psychopathology in the face of crimes of particular cruelty and brutality, it can be seen in four famous and recent Tuscan court cases (indicated with the initials of the names of the culprits: R.V.; EN; MA; DC;), concerning blood crimes (in the case of homicides or of attempted homicides), briefly described below:

- R.V.: the case concerning the barbarous killing, by a 50 -year- old plumber, of a young prostitute, only 26-year-old, who was found in May 2014 under a flyover, near Florence, crucified, bound, tortured, with a stick stuck in the rectum, which caused her a laceration and hemorrhage that led her to death;

- E.N.: the crime story pertains to the premeditated killing of a woman, by the former partner, after having pursued her, rammed with the car and hit her several times with a knife;

- M.A.: this is the crime of murder by a Florentine 40-year-old leather craftsman who, in June 2016, killed a Brazilian transsexual with whom he had a relationship, with 94 machete shots, and also he took away the life of the woman's friend, aged only 27 , striking 18 stab wounds;

- D.C.: the judicial case concerning the crime committed by a woman, against the wife of one of his former college mates, who slaughtered the woman and confessed that this act was moved by her envy for the happiness of the couple.

First of all, it should be noted that:

- in none of the cases treated, despite the cruelty of the crimes and of the actions, the experts found a psychiatric pathology in the defendants;

- in all cases, except one (M.A.), a personality disorder was found in the accused;

- $\quad$ in none of the processes analyzed, the judge considered a total defect existent, such as to exclude the capacity to understand and discern and only in the D.C. case, the Court of Cassation has deemed it necessary to recognize the semi-infirmity to the author of the crime;

- in all cases a lack of empathy of the culprits has been highlighted;

- the life story of all the treated criminals was characterized by the figure of at least one authoritarian parent incapable of showing affection, or by the figure absence;

in all cases, except in the second degree of the D.C. process, the judges have evaluated the responsibility of the subject by confirming the results of the psychic experts.

From the analysis of the legal proceedings dealt with it is clear the difficulty of identifying univocal criteria that allow the judge to evaluate the capacity to understand or discern of a defendant.

\section{Conclusions}

Beyond the method used by the experts, to achieve the demonstration of the capacity to understand or not of the accused, the judge's discretion remains in recognizing imputability of the person accused of a crime.

Friedrich Nietzsche, in the work Frammenti Postumi (18691889), captures the essence of the message that emerges from the considerations made in the present paper: "These wars, these religions, extremist morals, these fanatical arts, this hate party: it is nothing else that the great histrionics of impotence".

The spasmodic research of mono-causal, extreme and simplistic explanations leads to losing the overall vision and falling into categorizations of thoughts that cloud the mind by harnessing it in limiting visions altered by wrong preconceptions. The extremism, within religion, the politic or the science leads to a "dictatorship of thought" as well as an "insane vision" of the reality. The evolution of human being, in the medical, juridical and psychological fields, requires contextualization and weighting, in order to grasp the right teachings. A century and a half of psychiatry scientific evolution, and psychological, sociological, philosophical anthropological theories have not been enough to understand human behavior. And maybe that's right. 
People do not lend themselves to rigid categorizations: healthy, crazy, good, bad. Instead, they are complex organisms interacting with each other and with the environment. In understanding the human behavior and the bad or criminal behavior there are not magic formulas or genetic or neuroimaging tests capable of giving absolute answers. Only when we understand that the causes of human behavior cannot be enclosed in rigid and predefined concepts, the scientific evolution will provide valid ideas for improving law.

The extremization of neuroscience in the context of the Law, for example, could result in deleterious consequences, such as the stigmatization of the person on the basis of its genetic or neuronal structure or the ascertainment of guilt, innocence or mental illness on the basis of a brain x-ray. The scientific evolution must not turn into an escamotage to exclude the responsibility of the person acting, attributing the fulfillment of the fact to genetics or to the brain or neuronal structure, neglecting to evaluate the person, the individual.

Moreover, the neuroscientists themselves do not share the neuro-inductive positions, stating that "with the advent of modern forensic neuroscience there are prerequisites for a true innovation of the process, not through a substitution, but through an enrichment of the traditional psychiatric-forensic evaluation, in order to increase its objectivity and accuracy" 72 , placing neuroscientific contributions in a wider vision, which simultaneously takes into account the whole constellation of biological, environmental and social factors. It is, therefore, of fundamental importance to avoid that scientific contributions obscure the minds of legal operators who must be able to take advantage of the tools that scientific evolution provides them, but without abandoning themselves to an uncritical application of the same.

Science and Law must establish a sound collaborative dialogue and not a predominance of the former on the second. In fact, science can never be delegated the task of deciding the guilt or not of an individual, that it must remain a duty exclusively to the judicial body and which lends itself to blind automatisms, by virtue of constitutionally guaranteed protection to the person.

In conclusion, the hope is that both the technicians (of Law and of the Science) and the ordinary citizen can learn to be wary of argumentative simplifications that exile doubt, as if it were a pathology of logic, without realizing that the ability to doubt it represents the richness of the soul and leads not only to the scientific but also to the human improvement.

\section{References}

Algieri L., Neuroscienze e testimonianza della persona offesa, in Riv. It. Med. Leg., 33, 2012.

Arendt H., La banalità del male. Eichmann a Gerusalemme, Feltrinelli, Milano, 1993.

Baez S., Herrera E., Garcìa A.M., Manes F., Young L., Ibáñez A., Outcome-oriented moral evaluation in terrorists, in Nature Human Behaviour 1, 2017.

Barbieri C., Le neuroimaging in ambito medico - penalistico: alcune riflessioni critiche, in M.G. Ruberto, C. Barbieri, Il futuro tra noi. Aspetti etici, giuridici e medico-legali della neuroetica, Franco Angeli, Milano, 2011.

72 G. Sartori, A. Zangrossi, Neuroscienze Forensi, in Giornale Italiano di Psicologia, 2016, p. 707.
Baron S., Cohen S., La scienza del male. L'empatia e le origini della crudeltà, Raffaello Cortina Editore, Milano, 2012.

Bertolino M., La crisi del concetto di imputabilità, in Diritto penale in trasformazione, Milano, 1985.

Bertolino M., L'imputabilità e il vizio di mente nel sistema penale, Giuffrè, Milano 1990.

Bertolino M., Il breve cammino del vizio di mente. Un ritorno al paradigma organicistico?, in A. Santosuosso (a cura di), Le neuroscienze e il diritto, Pavia, 2009.

Bertolino M., Prove neuro-psicologiche di verità penale, in Dir. pen. cont., 2013.

Bianchi A., Gulotta G., Sartori G., Manuale di neuroscienze forensi, Giuffrè, Milano, 2009.

Boella L., Neuroetica. La morale prima della morale, Raffaello Cortina Editore, 2008.

Borum R., Psychological vulnerabilities and propensities for involvement in violent extremism, Behavioral Sciences and the Law, 2014, 32, doi:10.1002/bsl.2110.

Bottalico B., Il diritto penale e le neuroscienze, quali possibilità di dialogo?, online su www.academia.edu

Capitani E., Laiacona M., The evaluation of experimental data in neuropsychology, in G. Denes, L. Pizzamiglio (a cura di), Handbook of clinical and experimental neuropsychology, Hove, Sussex, Psychology Press, 1999.

Casellato M., La Muscatella D., Lionetti S., La valutazione di responsabilità del soggetto autore del reato. L'evoluzione delle neuroscienze e l'impatto sul sistema penale delle nuove metodologie scientifiche, in Rivista penale, n. 3, 2014.

Collica M.T., Il riconoscimento del ruolo delle neuroscienze nel giudizio di imputabilità, in Dir. pen. cont., 2012.

Corda A., Riflessioni sul rapporto tra neuroscienze $e$ imputabilità nel prisma della dimensione processuale, in Criminalia, 2012.

Damasio H., Grabowski T., Frank R., Galaburda A.M., Damasio A.R., The return of Phineas Gage: clues about the brain from the skull of a famous patient, in Science, vol. 264, 1994.

Di Giovine O., Un diritto penale empatico? Diritto penale, bioetica e neuroetica, Giappichelli, Torino, 2009.

Dollard J., Miller N.E., Doob L.W., Mowrer L.H., Sears R.R., Frustration and aggression (1939), trad. it. Frustrazione ed aggressività, Editrice Universitaria, Firenze, 1967.

Donelli D., Rizzato M., Io sono il tuo specchio. Neuroni specchio ed empatia, Torino, 2011.

Fabbri C., Cimino L., Serretti A., Genetics of impulsive-aggressive behavior: ready for application in forensic psychiatry?, Trad. it. Genetica dei comportamenti impulsivo-aggressivi: possibile applicazione in psichiatria forense?, Rassegna Italiana di Criminologia, Anno VI n. 1, 2013.

Freud S., Il disagio della civiltà, in Opere, vol. X, Boringhieri, Torino, 1929.

Freud S., L'io e l'Es, (1922), in Opere, vol. IX, Boringhieri, Torino, 2002.

Fornari U., Pennati A., Il metodo scientifico in psichiatria e psicologia forensi, parte $1^{\circ}$, in Brainfactor - Cervello $e$ Neuroscienze, 2011.

Galzigna M., La malattia morale. Alle origini della psichiatria moderna, Marsilio, Venezia, 1988.

Grandi C., Sui rapporti tra neuroscienze e diritto penale, in Riv. it. dir. proc. pen., 2014.

Grandi C., Neuroscienze e responsabilità penale. Nuove soluzioni per problemi antichi?, Giappichelli, Torino, 2016.

Hobbes T., De Cive, Marietti Editori, Torino, 1972.

Koselleck R.E., Schurr R., Hobbes-Forschungen, Duncker \& Humblot, Berlino, 1969.

Kruglanski A.W., Gelfand M.J., Bélanger J.J., Sheveland A., 
Hetiarachchi M., Gunaratna R., The psychology of radicalization and deradicalization: How significance quest impacts violent extremism, in Advances in Political Psychology, 35, Suppl. 1, 2014, doi: 10.1111/pops.12163.

Lavazza A., Sartori G., Neuroetica. Scienze del cervello, filosofia e libero arbitrio, Il Mulino, Bologna, 2011.

Libet B., Mind time. The temporal factor in consciousness, Harvard University Press, 2004.

Lombroso C., L'uomo delinquente, Quinta edizione, 1897, Bompiani, Milano, 2013.

Lykken D.T., The GSR in the detection of guilt, in Journal of Applied Psychology, 43, 1959.

Lykken D.T., Psychology and the lie detector industry, in American Psychologists, 29, 1974.

Mastronardi V., Leo S., Terroristi, Newton \& Compton, Roma, 2005.

Mastronardi V., Palermo G.B., Il profilo criminologico. Dalla scena del crimine ai profili socio-psicologici, Giuffrè, Milano, 2005.

Mastronardi V., De Luca R., I serial killer. Il volto segreto degli assassini seriali: chi sono e cosa pensano? Come e perché uccidono? La riabilitazione è possibile?, Newton \& Compton, Roma, 2009.

Mastronardi V., Manuale per operatori criminologici e psicopatologi forensi, Giuffrè Editore, Milano, 2012.

Mastronardi V., Iandolo M., Il Lupo Solitario: terrorismo ideologico - religioso nella società liquida, Revista URBE et IUS, Buenos Aires, 13, 2014.

Mazzaglia S., Nuova teoria degli anti-neuroni e anti-neuroni specchio. L'anti-empatia, l'anti-risonanza, l'antirispecchiamento, le anti-emozioni tra scienze dell'educazione, pedagogia visiva, neuroscienze, criminologia, filosofia, diritto penale, Edizioni Univ. Romane, 2015.

Merzagora Betson I., Il colpevole è il cervello: imputabilità, neuroscienze, libero arbitrio: dalla teorizzazione alla realtà, in Riv. it. med. leg., 2011.

Merzagora Betson I., Colpevoli si nasce? Criminologia, determinismo, neuroscienze, Raffaello Cortina, Milano, 2012.

Miller E.N., The Frustration-Aggression Hypothesis, in Psychol Review, 48, 1941.

Correspondence: Celeste Oranges.

E-mail: Celeste.oranges@gmail.com

Key words: Malice, imputability, Orlando Reform, Forensic psychopathology, criminal trial.

Parole chiave: Cattiveria, imputabilità, riforma Orlando, psicopatologia forense, processo penale.

Palabras clave: Maldad, imputabilidad, reforma Orlando, psicopatología forense, proceso penal.

Received for publication: 4 July 2018.

Revision received: 4 August 2018.

Accepted for publication: 20 August 2018.

This article is distributed under the terms of the Creative Commons Attribution Noncommercial License (by-nc 4.0) which permits any noncommercial use, distribution, and reproduction in any medium, provided the original author(s) and source are credited.

CCopyright C. Oranges, 2018

Licensee PAGEPress, Italy

Rivista di Psicopatologia Forense, Medicina Legale, Criminologia 2018; $23: 34$

doi:10.4081/psyco.2018.34
Pietrini P., Responsabilmente: dai processi cerebrali al processo penale. Prospettive e limiti dell'approccio neuroscientifico, in AA.VV., La prova scientifica nel processo penale (a cura di De Cataldo Neuburger L.), Padova, 2007.

Raighero C., Neuroni specchio, Bologna, 2010.

Raine A., L'anatomia della violenza, Mondadori, Milano, 2016.

Rizzolatti G., Sinigaglia C., So quel che fai, il cervello che agisce ed i neuroni specchio, Ed. R. Cortina, Milano, 2006.

Sammicheli L., Forza A., De Cataldo Neuburger L., Libertà morale e ricerca processuale della verità: metodiche neuroscientifiche, in Bianchi, Gulotta, Sartori (a cura di), Manuale di Neuroscienze Forensi, Giuffrè Editore, Milano, 2009.

Samson V., I Bersenkir. I guerrieri-belve nella Scandinavia antica, dall'età di Vendel ai Vichinghi (VI-XI secolo), Edizioni Settimo Sigillo, Roma, 2016.

Sartori G., Agosta S., Menzogna, cervello e lie detection, in Bianchi, Gulotta, Sartori (a cura di), Manuale di Neuroscienze Forensi, Giuffrè Editore, Milano, 2009.

Sartori G., Rigoni D., Sammicheli L., L'orologio di Libet e la responsabilità penale, in Gulotta-Curci (a cura di), Mente, società e diritto, Milano, 2010.

Sartori G., Zangrossi A., Neuroscienze Forensi, in Giornale Italiano di Psicologia, 2016.

Silke A., Holy warrior: Exploring the psychological processes of Jihadi radicalization, European Journal of Criminology, 2008, 5, 99, doi: 10.1177/1477370807084226

Terracina D., Neuroscienze: lo studio della morfologia del cervello determinante nello stabilire il vizio parziale di mente, in Guida al diritto, n. 5, 2012.

Tonini P., La prova penale, Cedam, 2000.

Zara G., Neurocriminologia e giustizia penale, in Cassazione Penale, n. 2, 2013.

Zimbardo P., The Lucifer effect: Understanding how good people turn evil, Random House, New York, 2007, trad. it., L'effetto Lucifero. Cattivi si diventa?, Raffaello Cortina, Milano, 2008.

\section{Case Law}

Cass., 23 ottobre 1978, n. 4795, in Giust. pen., II, 1979.

Cass., Sez. V, 16 luglio 1981, n. 4646, in Giust. pen., II, 1982.

Cass., Sez. I, 26 novembre 1986, n.866, in Cass. pen., 1990.

Cass. Sez. I, 2 luglio 1990, n. 313, in Giust. pen., 1991.

Corte Cost., 27 giugno 1996, n. 238 in www.cortecostituzionale.it

Cass., Sez. I, 25 marzo 2004, n. 16940, Foro.it, Rep. 2004, voce Imputabilità n. 10.

Corte d'Assise di Appello di Trieste, $1^{\circ}$ ottobre 2009, n. 5, in Riv. Pen., 2010.

G.I.P. Como, 20 maggio 2011, n. 536, in Guida al diritto (on line), 2011.

\section{Webliography}

https://www.academia.edu

https://www.archiviopenale.it

https://www.cortecostituzionale.it

https://www.cortedicassazione.it

https://www.dejure.com

https://www.diritto24.ilsole24ore.com/guidaaldiritto

https://www.foroitaliano.it

http://www.giurisprudenza.penale.com

https://www.iusexplorer.it/Rivista/RivistaItalianadiMedicinaLegale http://www.palazzochigi.it 